\title{
The Role Of Government's Executive And The Legislative Body In Budgeting Management On Realization Of Local Government's Good Governance
}

\author{
Dr. Pasaman Silaban, S.E, M.S.B.A. ${ }^{1}$ \\ ${ }^{1}$ Universitas HKBP Nommensen, Medan, Indonesia
}

\begin{abstract}
This piece of research intends to explore and analyze the local government's executive role in developing and implementing the governmental budget as well as the role played by the legislative body in approving and supervising the budget, to examine the respective influence of these roles on the realization of good governance.This research study comprises analytic observation made by way of the survey method, and is non-experimental in nature. Sample collection has been arranged through purposive method, which means by considering all members of the local population, except members that categorized as new local governments. The Research Unit is made up of 13 local governments at Regency level and 6 local governments at the Municipal level. The respondents are local government executives and the Local Legislative Body's Budgetary Committee. The total number of respondents amounts to 540 and the completed questionnaires amount to 420. The analytical method employed is the so-called Path Analysis. The result of path coefficient shows that local government's executive role moderately high influential in terms of affecting the realization good governance, and based on hypothesis test, its influential is significant. Meanwhile, the result of path coefficient shows that the legislative body's role weakly influential in terms of affecting the realization good governance, but based on hypothesis test, its influential is not significant. Furthermore, the result of path coefficient shows that local government's executive and the legislative body's role simultaneously influential in terms of affecting the realization (enhancement) of good governance, and based on hypothesis test, its influential is significant. These findings are supported by previous research and various theories based thereon.
\end{abstract}

Keywords: Budgeting Process, local government's executive role, legislative body's role, good governance

\subsection{Background}

\section{Introduction}

In Indonesia, the development of management and public administration is not so perfect, but by the implementation of local autonomy there is a new era in government administration and public management. Act number 32 and number 34 of 2004 provide a new hope for the development of autonomy actually. The development of local autonomy is held by consider the principles of democracy, society participation, justice and local potency and diversity.

One of local government aspect in the aforementioned Act is local financial and budget management. Local budget or Local Revenue and Expenditure Budget is an instrument of the main policy for the local government. Budget is a potential tool for the government in show its policies and as a manifestation of financial from them who elected by people (Castaneda, 2000). Therefore, the local budget has a central position in development of local government capability and effectiveness.

In the implementation of wide, real and accountable local autonomy it needs a new formulation related to the local financial management. Generally, the financial management is a financial planning, formulation and budget implementation, the payment to and from the public institutions, accounting, financial statement and internal evaluation (Premchand, 2000). The consequence of local autonomy based on the aforementioned Act cause the change in local financial management in Indonesia. The change is related to the requirement of budget reformation in local financial management system.

In the local financial management and budget, the principle of comprehensiveness and discipline, flexibility, predicted, rectitude, transparency and accountability is required in its implementation (World Bank, 1997). The aforementioned principles are a part of good governance. Therefore, these principles must be applied in each local budget cycle. The local budget cycle is consist of formulation./planning, implementation, reporting and evaluation steps (Asian Development Bank, 2000). In the local financial management, these main principles are corridor for them who related to the arrangement and implementation of local budget. It means that the main principles will assure that local financial management always oriented to the public interest.

Generally the formulation/planning step is implemented by executive or anyone who assigned for that and involves the budget development analysis or revenue planning based on the available income estimation. 
This step followed by the budget estimation that submitted to the legislative institute for respond or approval. After be approved, the budget is implemented and then followed by reporting and evaluation. In reporting and evaluation step, the implementation must be evaluated in order to measure the performance of local government and its units.

In planning step, the system analysis is applied to determine the objectives and identify the related solution for the achievement of the objectives. In programming step, the facilities will be reviewed and compared to the identified solution in planning step. In this context, budgeting is an integrated program of decision making and to make a distribution to the administrative units through independent program and organization affiliation. Therefore, what a relation will be achieved and how to achieve it and what the resources used to achieve it is a main focus of expenditure management using performance based budgeting system.

The management in planning aspect is required to make the budgeting process indicates the background of decision making maximally in determining the public policy, priority scale, allocation and distribution of resources by the involvement of society. Therefore, in process and mechanism of budgeting determined in Government Regulation of RI No. 58 of 2005 it will determine who have responsibility and what the base of the accountability either between executive and legislative or in internal side of the executive.

The basic substance of budget planning is the role and function of legislative institute in determining the direction and budget policy. Principally, although legislative has a big role in supervision and legalization, but they also have role in planning. The local government executive has an important role in planning and implementation, but they also have a supervision role on the implementation of programs or activities in government organization.

The communication between legislative institute and society is a form of two ways communication. Legislative institute will accept the society aspiration and they also have liability to provide the society with any information related to the budgeting process. The gathering of information is aims to obtain the data/information about the society need and desire that will be realized in the form of direction and public policy of budget. The communication between legislative institute and local government executive as a partner is a support communication and not for neglect the other ones. Legislative institute as society representative must able to submit the society aspiration to the local government in determining the direction and public policy of budget as authority of legislative institute that will be implemented by local government.

In local autonomy context, there are three main aspects that support the success of local autonomy, i.e. supervision, controlling and investigation. The three aspects are differed either by conception or application. Supervision refers to the action and activity of party other than executive (i.e. society and legislative institute) to supervise the performance of government. Controlling is a mechanism that implemented by executive (local government) in order to assure the implementation of system and management policy in order to realize the objective of organization. Investigation is activity implemented by party who has independency and professional competency to evaluate whether the performance of local government is based on the determined performance standard.

In order to increase the performance of local government, either executive or legislative, it needs specific ideas as mentioned in good governance. World Bank (1997) defines good governance as a solid and accountable implementation of development management based on democracy principles and efficient market, to avoid one of allocation of investment fund and prevent the corruption either politically or administratively, to implement the budget discipline and building of law and politic framework for the growth of business activities.

Nevertheless, what will hope from the role of local government executive or legislative institution in the implementation of good governance has not yet realized based on the desires of reformation that said in Act of Local Autonomy. According to Act No. 32 and Act No. 33 of 2004, executive and legislative as elements of local government institution is a parallel partner. But in fact, either executive or legislative has not yet based on their determined mission and function. It is not a surprise if there is overlapping or intervention between them. The role of local legislative institute is assumed is over and the function of bureaucracy has not yet indicates a role as transparent, accountable public officer who has initiative and creativity.

In any case, the local government executive is not transparent in local financial management especially in budgeting process that cause a suspicion of the local legislative institute. This condition cause inharmonious and conflict between executive and legislative and then cause the budget is implemented without approval or legalization from the local legislative institute. A different condition also found in which local government is arrogant in which they assume that they have a higher authority than local government executive. This condition always influences the delay in legalization or approval of budget. This event will disturb the implementation process of good governance and has a potency influence the local government performance. 


\subsection{Research Problem}

Based on the background of study and any aforementioned cases, the question for the problem of research is formulated as follows:

"How far the influence of local government executive in arrangement and implementation of budget, and the role of local legislative institute in legalization and supervision of local government budget, either partially or simultaneously in the realization of good governance to the local government officer?"

\subsection{Research Objective}

This study aims to find and to verify the role model of executive and legislative in realization of good governance. The results of this research will supply any information and useful finding for the development of economic science specially the local financial management.

\subsection{Research Significance}

By understanding the influence of executive and legislative roles in budgeting process for the realization of good governance of local government, it hope this research will useful for the development of science, as source of references and as reference and contribution in problem solving and decision making related to the budgeting process and good governance.

\subsection{Theoretical Review}

\section{Theoretical Review And Hypothesis}

The role is an action to show a desired behavior related to the position in a social unit. While the managerial role is consist of any roles such as decision making in a role as entrepreneur. By this role, a leader seeks an opportunity and initiates any activities for the advantages of organization. Based on this description, it said that the role indicates participation of anyone in achieve a determined goal. The managerial role of government officer enables the achievement of the efficient and effective governance mechanism.

The implementation of managerial role of government officer in budgeting process is an activity to clarify the function, authority and accountability based on his position. Therefore, by the implementation of participative management, the involvement of the interested party in the governance implementation specially in decision making will support the achievement of the goal effectively as determined in New Public Management. The local government executive as government officer must accountable in implement his role. Local government executive must take a responsibility of the implemented role based on task, function and authority assigned to him. (Joko Widodo, 2001).

The operational and financial planning is a main objective of budgeting process (Hackbart \& Ramsey, 1999; Allen \& Tommasi, 2000). The objective of budget planning is to develop a suggestion of government action for the determined period in the future. This budgeting process supplies a mechanism of decision making in achievement of government service plan, allocation of resources and work method required in the implementation of the plans and to determine a priority of expenditure based on available revenue (Premchand, 2000). In other word, the budgeting process did not take a decision automatically but the decision must be taken carefully in each administration level of government organization structure.

Therefore, executive (Local government leader and heads of offices) have an important role in initial process of budgeting and in the implementation of the budget in local government organization (World Bank, 1998; Santiso, 2005; Act of RI No. 32 of 22004). In each steps of the budgeting process, the executive must implement the principles of transparency, accountability, efficiency and effectiveness. According to the World Bank, the transparency, efficiency and effectiveness is a principle of good governance that related to any activity.

In transparency principle, each steps ion budgeting process must be implemented transparently to avoid the interest of group or section ion local government administration. The transparency must build on the freedom in get any information. The important information is not only about market but also in a design of public activity that influence the economic living and social prosperity. On the contrary, the weakness of transparency in public administration will be a main obstacle in the implementation of policy and results of economic social (Wanath \& Kaufman, 1999). Furthermore, Mardiasmo (2004) said that the transparency in financial management specially in local budget must build accountability between local government and society for the clean, effective, efficient and responsive local government to the society interest and aspiration.

Furthermore, the executive must has accountability on anything related to the implementation of budget. Accountability is a responsibility to the public for each activities that had be implemented. Public accountability is a decision maker must have behavior based on the mandate received by him. Therefore, the formulation of collective policy and the results of the policy must be accessible and communicable vertically or horizontally effectively (Mardiasmo, 2004). Then Goddart (1999) describes that the budgeting system is an important organizational process that related to the accountability. 
Based on the condition, the transparency and accountability of budget arrangement, budget determining and budget calculation is a realization of government accountability to the society. Based on the Code of Good Practices on Fiscal Transparency that introduced by IMF, in development process of public discourse as one of supervision instrument in local fiscal management, it necessary to provide the society with access to the information about performance and accountability of the budget.

The principle of efficiency and effectiveness is a depiction of value for money. Efficiency means that the using of society fund by executive will produce the maximum output (effectiveness), while effectiveness means that the local executive as fiscal manager must use the budget for the achievement of the target or objective of public interest. The value for money is a bridge to take the local government in the achievement of good governance, namely the transparent, economic, efficient, effective, responsive and accountable local government. (Mardiasmo, 2004). Therefore, the realization of accountability, efficiency and effectiveness as a part of good governance requires the local government implement the executive role in prepare the budget planning that related to one of accountability report in which the report contain anything related to the efficiency and effectiveness.

It is useful to make a concept of total budget system as a process of budget cycle that integrated and continuously in which the legislative has a key role in each step of the cycle (Stapenhurst, 2004). The cycle consists of institutions, the form of government system that known as executive, public service, civil society, and legislative. In order to make the total budget cycle work transparently, openly and accountably, the functions such as budget planning, revenue and expenditure allocation, financial statement, internal audit and evaluation and public accountability must involves the society and public group.

Legislative has a role to accommodate the aspiration and feedback from the group of: entrepreneur, academician, society organization and other parties before the budgeting process is begin. The weakness in budgeting process is influenced by politic factors that played by legislative specially in uncertainty of accountability and overlapping of job description (Wanath \& Kaufman, 1999). Therefore, the legislative must show their role as authority institution in legalize the budget draft submitted by executive. Legislative must implement their political capability professionally in discuss and evaluate the budget draft and not involves in disputation that neglect the budget planning (Stapenhurst, 2004).

The institution with final accountability on the mistake of executive in fiscal management specially in budgeting is legislative. Legislative has authority to access the budget document totally. The implementation of authority is in the implementation of their role as supervisor of the budget implemented by executive (Castaneda, 2000; Act of RI No. 32 of 2004; Government Regulation of RI No. 58 of 2005). Therefore, the expenditure must be minimized for the efficiency and effectiveness of the budget using that provide a contribution ion the realization of good governance. The supervision in this context is implemented by legislative as managerial function.

As supervision institution, legislative must help in improve the using of public fund and support the public institutions to manage the fiscal management efficiently (Schick, 2002). Furthermore, Pelizzo and Stapenhurst (2004) said that by the increasing of research carefully on budget, legislative will help improve the asymmetric of information between local government and society, and to expose the budget to the public and social supervision.

Good governance is a dominant central issue in public administration management because there is aspect related to the accountability and performance. Good governance is defined by World Bank as implementation of solid and accountable development management that based on democracy and efficient market, avoid misallocation of the scarce investment fund, prevention of corruption, and implement the budget discipline. Therefore, a realization of good governance is a solid and accountable, efficient and effective governance implementation. (Sedarmayanti, 2003).

\subsection{Hypothesis}

Based on the problem of research and theoretical review, the hypothesis is submitted as temporarily respond on the research problem in which the trueness must be tested empirically.

The hypothesis of research is :

The role of local government executive in arrangement and implementation of budget, and the role of local legislative institute in budget legalization and supervision either partially or simultaneously has a significant influence to the realization of good governance in the local government administration.

\subsection{Research Method}

\section{Method Of Research}

The design of study applied in this research is an explanatory research because this is a research that explains a causal correlation between variables. There are two types of variables, i.e. independent variable, i.e. (1) the role of executive in arrangement and implementation of budget; (2) the role of legislative in legalization 
and supervision of budget, and endogenous variable namely a realization of good governance. Each variable is measured by Likert scale with five participation scale.

\subsection{Population and Sample}

In this research, the sampling method is purposive sampling namely the determining of sample by certain consideration because the number of local government will be studied is 25 units but 6 of them are the new local governments. Therefore, the analysis unit is 19 local governments in regency/city level. The respondents are the executive officers (Local government leader and heads of offices) and legislative (Budget Committee).

\subsection{Design of Hypothesis testing}

The model of path analysis structure that depict a structural correlation between variables is depicted in the below figure :

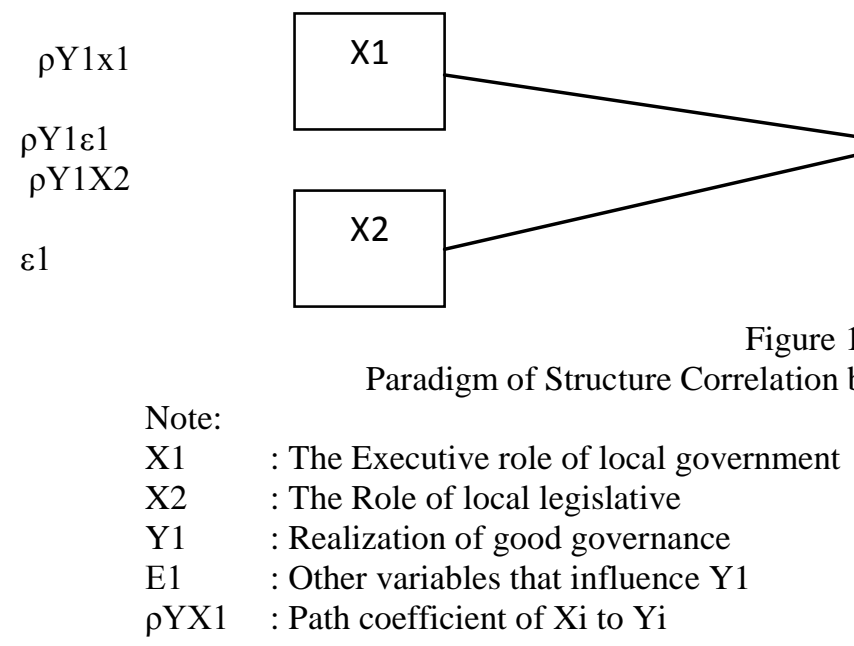

The influence of each variable to Y1 is determined by value of $\rho$ Yici; $\mathrm{I}=1,2$ as shown in the structural equation :

$\mathrm{Yi}=\rho_{\mathrm{Y} 1 \mathrm{X} 1} \mathrm{X} 1+\rho_{\mathrm{Y} 1 \mathrm{X} 1} \mathrm{X} 2+\rho_{\mathrm{Y} 1 \varepsilon 1}$

The hypothesis test to the influence of each variables $\mathrm{Xi}$ to $\mathrm{Yi}$ is implemented by test the hypothesis as follows:

H0: $\rho_{\mathrm{Y} 1 \mathrm{X} 1}=0$

$\mathrm{H} 1: \rho_{\mathrm{Y} 1 \mathrm{X} 1}>0$

The value of $\rho_{\mathrm{Y} 1 \mathrm{X} 1}$ is a path coefficient that obtained or calculated based on the data in order to determine the partial influence between the role of executive and the realization of good governance and the influence of legislative role ion realization of good governance.

The direct influence of variable Xi to Y partially indicated by the determination coefficient of each independent variable. The value of determination coefficient of each independent variable is calculated by quadrate of variable independent $\left(\rho_{\mathrm{YXi}} 2\right)$. The determination coefficient is situated in the interval of $0 \leq\left(\rho_{\mathrm{YXi}} 2\right) \leq$ 1 .

If $\rho_{\mathrm{YXi}} 2$ is approach to 1 , the higher of proportion of contribution of independent variable partially in explain the dependent variables variation and in contrary, if $\rho_{\mathrm{YXi}} 2$ is approach to 0 , the smaller of proportion of contribution of independent variable partially in explain the variation of dependent variable.

In order to test the simultaneous influence of variable $\mathrm{Xi}$ and $\mathrm{Y}$, the hypothesis is tested as follows:

$\mathrm{X} 1$ and $\mathrm{X} 2$ to $\mathrm{Y} 1$

$\mathrm{H} 0: \rho \mathrm{Y} 1 \mathrm{X} 1=\rho \mathrm{Y} 1 \mathrm{X} 2=0$

$\mathrm{H} 1$ : Not less than one of $\rho \mathrm{Y} 2 \mathrm{x} 1 \neq 0 ; \mathrm{i}=1,2$

The simultaneous influence of variable $\mathrm{Xi}$ to $\mathrm{Y}$ is indicated by determination coefficient $\left(\mathrm{R}^{2}\right.$ or $\mathrm{R}$ square). The value of determination coefficient is found in interval of $0 \leq R^{2} \leq 1$.

If $\mathrm{R}^{2}$ approach to 1 , the bigger of proportion of contribution of independent variable simultaneously in explain the variation of dependent variable and conversely if $\mathrm{R}^{2}$ approach to 0 , the smaller of proportion of contribution of independent variable simultaneously in explain the variation of dependent variable.

The criteria applied in determining the high or lower of correlation between variables is Sevilla Classification $(1997 ; 280)$ as follows:

Between \pm 0.80 to \pm 1.00 : high correlation 
Between \pm 0.60 to \pm 0.79 : moderately high correlation

Between \pm 0.40 to \pm 0.59 : moderately correlation

Between \pm 0.20 to \pm 0.39 : low correlation

Between \pm 0.01 to \pm 0.19 : negligible correlation

The significant test tool is t-test for variable individually or partially and F-test for simultaneous variable or by compare the sig value from the calculation using SPSS program with the probability value with $\alpha=0.05$ $(5 \%)$. In order to know the significance of correlation and path analysis, it compares the probability 0.05 to the Sig probability value based on the decision making as follows:

1. If the probability $0.05 \leq \mathrm{sig}$, Ho is accepted and $\mathrm{H} 1$ is rejected, means is not significant.

2. If probability $0.05>\mathrm{sig}$, Ho is rejected and $\mathrm{H} 1$ is accepted, means is significant.

\subsection{The Results of the Hypothesis Testing and Discussion}

\section{Result And Discussion}

Figure 2.

By using SPSS program it obtain the path coefficient between X1 and X2 and Y1 as shown ion below

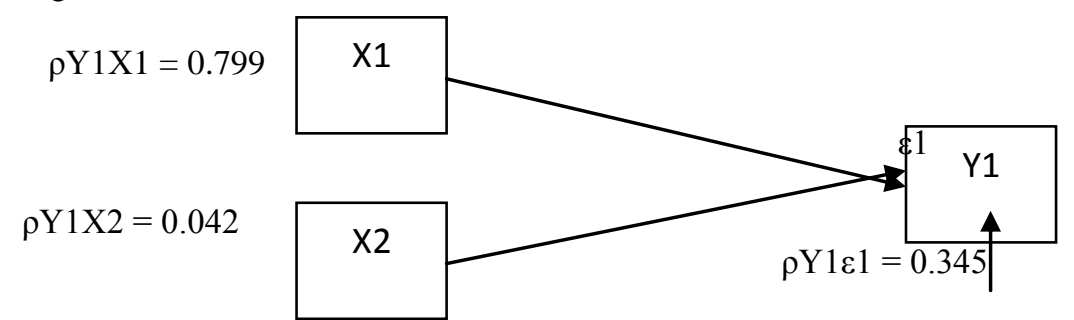

Figure 2

Path Diagram Model of Structural Equation of Influence of $\mathrm{X} 1$ and $\mathrm{X} 2$ to $\mathrm{Y} 1$

Note:

$\mathrm{X} 1=$ The role of local government executive ion arrangement and implementation of budget

$\mathrm{X} 2=\quad$ The role of local legislative ion legalization and supervision of budget

$\mathrm{Y} 1=\quad$ Realization of Good Governance

The detail of results of path coefficient partially for the aforementioned variables is shown in table 1 .

Table 1

The Partial Influence of X1 and X2 to Y1

\begin{tabular}{|l|l|l|l|}
\hline No & Variable & Path Coefficient & Remark \\
\hline 1 & $\begin{array}{l}\text { The role of local government executive ion arrangement and implementation } \\
\text { of budget to the realization of good governance }\end{array}$ & $\rho Y 1 X 1=0.799$ & Has influence \\
\hline 2 & $\begin{array}{l}\text { The role of local legislative in legalization and supervision of budget to the } \\
\text { realization of good governance }\end{array}$ & $\rho Y 1 X 2=0.024$ & Has influence \\
\hline
\end{tabular}

Source: Processed primary data

Based on the value and results of path coefficient as shown in Table 1, it describes as follows:

1. The role of local government executive in arrangement and implementation of budget has an influence to the variable of realization of good governance that indicated by the value of path coefficient for 0.799.

2. The role of local legislative institute in legalization and supervision of budget has influence to the variable of realization of good governance that indicated by the value of path coefficient for 0.042 .

The influence of X1 and X2 to Y1 is classified into direct influence, indirect influence and total influence of variable $\mathrm{X} 1$ and $\mathrm{X} 2$ to $\mathrm{Y} 1$ :

Table 2

Calculation of the Influence of Variable X1 and X2 to Y1

\begin{tabular}{|c|c|c|c|c|c|}
\hline \multirow{2}{*}{ Variable } & \multirow{2}{*}{ Path Coefficient } & \multirow{2}{*}{$\begin{array}{c}\text { Direct Influence (in } \\
\% \text { ) }\end{array}$} & \multicolumn{2}{|c|}{ Indirect Influence (in \%) } & \multirow{2}{*}{$\begin{array}{l}\text { Total } \\
\text { influence }\end{array}$} \\
\hline & & & $\mathrm{X} 1$ & $\mathrm{X} 2$ & \\
\hline $\mathrm{X} 1$ & 0.799 & $63.85 \%$ & & $0.73 \%$ & $64.58 \%$ \\
\hline $\mathrm{X} 2$ & 0.042 & $0.19 \%$ & $0.73 \%$ & & $0.92 \%$ \\
\hline \multicolumn{5}{|c|}{ Total influence of $\mathrm{X} 1$ and $\mathrm{X} 2$ to $\mathrm{Y} 1$} & $65.50 \%$ \\
\hline \multicolumn{5}{|c|}{ The influence of other factors $(\varepsilon)$} & $34.50 \%$ \\
\hline
\end{tabular}

Source: Processed Primary Data

Based on the results presented in above table, it explains as follows:

1. The direct influence of local government executive in arrangement and implementation of budget to the realization of good governance is 0.799 (79.9\%), indirect influence through the role of local legislative 
institute ion legalization and supervision of budget is $0.0073(0.73 \%)$ and total influence is 0.6458 $(64.58 \%)$. Based on its influence, the role of executive in arrangement and implementation of budget to the variable of realization of good governance, either direct influence or total influence has a strong influence.

2. The direct influence of local legislative institute in legalization and supervision of budget to the realization of good governance is $0.0019(0.19 \%)$, indirect influence local government executive in arrangement and implementation of budget is $0.0073(0.73 \%)$ and total influence is $0.0092(0.902 \%)$. Based on its influence, the role of local legislative in legalization and supervision of budget to the variable of realization of good governance, either direct influence or total influence has a weak influence.

3. Simultaneously it indicates that the role of local government executive in arrangement and implementation of budget and the role of legislative in legalization and supervision of budget influence the realization of good governance. This is indicated by value of $\mathrm{R}^{2}$ or $\mathrm{R}$ square for $0.655>0$. Total influence of the role of local government executive ion arrangement and implementation of budget and the role of local legislative ion legalization and supervision of budget to realization of good governance is $0.655(65.5 \%)$ that categorized into strong influence.

4. The influence of other factors to the realization of good governance that did not observed in this research is $0.345(34.5 \%)$. The influence of other factor indicated that there are any other factor that did not studied in this research has an influence to the realization of good governance.

\subsection{Discussion of Path Coefficient Result}

A significant influence of the role of local government executive in the realization of good governance indicates that local government executive had implement their role effectively This condition is based on the results of survey in which more of respondent in this research is provide a good respond that indicates that local government executive pay attention in the realization of good governance.

In budget arrangement function, respondent also provide a good respond on activities related to the budget arrangement. Based on the results of survey indicates that activity related to the implementation of budget proved that local government executive has pay attention to the importance of budget implementation for the realization of good governance.

Based on the influence of role of local government executive to the realization of good governance is $63.84 \%$ in a strong category indicates that local government executive in regency/city level has influence ion realization of good governance. This is supported by Hacbart \& Ramsey (1999) in their statement that specifically the budgeting process has target to operational and fiscal planning. The operational and fiscal planning is implemented by executive that will be developed in detail program/activities. The arrangement of detail program/activity is easy for implementation and supervision for the realization of the program efficiently, effectively and economically.

The results of the influence of local government executive role in the realization of good governance is suitable to the opinion of Premchand (2000) who state that budgeting process must provide a mechanism of decision making for the realization of the plan determined by government, allocation of resources and work method required for the implementation of the plan, and to determine the priority of using of available fund. The budgeting process did not make a decision automatically but the decision must taken by the involvement of echelon in government organization structure. The results of descriptive survey of questionnaire indicates that the local government executive do the budgeting process effectively either in planning, budgeting arrangement and the implementation of budget.

Based on the results of path coefficient value it indicates that partially the role of local legislative institute in legalization and supervision of budget to the realization of good governance has a weak influence that indicated by the direct influence value for $0.19 \%$. The strong and weakness of the influence refers to the opinion of Sevilla (1997) that determine $0.19 \%$ is on weak classification. This indicates that the role of legislative in budgeting process especially in legalization and supervision function of budget influence the realization of good governance.

Wanath \& Kaufman (1999) said that the weakness in budgeting process is influenced by political factor that played by legislative specially in uncertainty of accountability and overlapping of accountability. This also suitable to Shick (2002) that legislative must aware their capacity as people who has role in the budgeting process, but the political influence that disturb them in do their function may occurred. Stapenhurst (2004) describes that Legislative must use their political capability professionally in discuss and evaluate the budget and not to make disputation that neglect the budget.

Anything that cause the weak influence of legislative institute in budgeting process for the realization of good governance is the implementation of performance valuation. The performance valuation is auditing for appraisal of economic level, efficiency and effectiveness of implementation of program.

The objective of performance audit is to increase the accountability of legislative as accountability to the society (Mardiasmo, 2004). The weakness in supervision also influence the realization of good governance 
as said by Santiso (2005), in which by the supervision to the executive policy, legislative trace the mistake in the implementation of budget. In other words, legislative has a role in increasing of transparency of the using of public fiscal and integrity of public financial.

Based on the path coefficient it indicated that simultaneously the role of local government executive in arrangement and implementation of budget and the role of local legislative in legalization and supervision of budget to the realization of good governance has a moderate or strong influence that indicated by the value of direct influence for $65.50 \%$. This indicates that the role of executive in budgeting process specially in arrangement and implementation of budget and the role of local legislative in legalization and supervision of budget influence the realization of good governance.

\subsection{Testing of Hypothesis}

In order to test the significant influence of variable $\mathrm{X} 1$ and $\mathrm{X} 2$ simultaneously to variable $\mathrm{Y} 1$, the hypothesis is tested as follows:

$$
\begin{aligned}
& \mathrm{H} 0: \rho \mathrm{Y} 1 \mathrm{X} 1=\rho \mathrm{Y} 1 \mathrm{X} 2=0 \\
& \mathrm{H} 1: \text { Not less than one of } \rho \mathrm{Y} 1 \mathrm{X} 1 \neq 0 ; \mathrm{I}=1,2
\end{aligned}
$$

Based on output of regression calculation to get the path coefficient simltaneously by using SPSS program, the value of $\mathrm{R}$ square is 0.655 and the probability value ( $\mathrm{sig}$ ) on $\mathrm{F}$ is 0.000 for executive role path (X1) and legislative role $(\mathrm{X} 2)$ to the realization of good governance.

Furthermore, the partial test is conducted to see the influence of each independent variable by hypothesis testing as follows:

a) $\mathrm{H} 0: \rho \mathrm{Y} 1 \mathrm{X} 1=0$

$\mathrm{H} 1: \rho \mathrm{Y} 1 \mathrm{x} 1>0$

Hypothesis in sentence:

H0: the role of executive in arrangement and implementation of budget has not a significant contribution to the realization of good governance.

H1: the role of executive in arrangement and implementation of budget has a significant contribution to the realization of good governance.

Based on the output of regression calculation using SPSS program, the path coefficient between executive role (X1) and the realization of good governance (Y1) is 0.799 with the probability value (sig) of tvalue is 0.000 .

Therefore, the probability value $0.05>\mathrm{sig}=0.000$, so Ho is rejected and $\mathrm{H} 1$ is accepted, it means that the role of executive in arrangement and implementation of budget has a significant influence to the realization of good governance. The discussion of the influence had presented in sub-section 4.2.

Based on the previous description that the influence of executive role to the realization of good governance is in strong category and statistically had tested that the influence is significant. This condition is also provide by the respond on questionnaire that submitted by executive and legislative in which the results provide a strong support, either from the executive respondent or legislative to the managerial function that implemented by executive. The respond support the executive position in play the rule and function as planner, arranger, and implementation of budget is an indication that executive has a significant contribution to the realization of good governance in regency and city government.

b) H0: $\rho \mathrm{Y} 1 \mathrm{X} 1=0$

$\mathrm{H} 1: \rho \mathrm{Y} 1 \mathrm{x} 1>0$

Hypothesis in sentence:

HO: the role of legislative in legalization and supervision of budget has not a significant contribution to the realization of good governance.

$\mathrm{H} 1$ : the role of legislative in legalization and supervision of budget has a significant contribution to the realization of good governance

Based on output of regression calculation to get the path coefficient partially using SPSS program, the path coefficient between the role of executive (X1) in realization of good governance (Y1) is 0.042 with the probability value (sig) on t value is 0.781 (Appendix). Therefore, the value of probability $0.05<\mathrm{sig}=0.781$ so Ho is accepted and $\mathrm{H} 1$ is rejected, it means that the role of legislative in legalization and supervision of budget has not a significant influence to the realization of good governance. 


\subsection{Conclusion}

\section{Conclusion And Suggestion}

This research study and review the influence of local government executive role in arrangement and implementation of budget and the role of local legislative in legalization and supervision of the budget to the realization of good governance. The results of research indicate that:

1. The role of local government executive in arrangement and implementation of budget, and the role of local legislative in legalization and supervision of budget has a partial and simultaneous influence to the realization of good governance.

2. The partial influence of the both of variables is in a contradiction in which the influence of executive role to the realization of good governance is in strong category, while the role of legislative in realization of good governance is in weak category. And based on statistical test it obtain that the influence of executive role ion budgeting process to the realization of good governance is significant. The significant influence of the role of executive to the realization of good governance is supported by the respond on questionnaire or survey in which both of sides provide a strong support for the position of executive in implement their function and role ion budgeting process.

3. The legislative role in realization of good governance has insignificant influence. The insignificant influence of the role of legislative is indicated by the weakness of the partial influence between the role of legislative to the realization of good governance. There are any causal factors, i.e. (1). The background condition and a few of experiences on budgeting. (2) the lack of understanding and attention to the performance audit that related to the economic, efficiency and effectiveness level of the implementation of program and (3). The weakness of the supervision functions to the budgeting process while they have authority for that. While the simultaneous influence is in strong category and statistically based on hypothesis testing, it has a significant influence.

\subsection{Suggestion}

Based on results or aforementioned conclusion, there are any suggestions either to the local government as analysis unit in this research and specially to the next researcher who interest in continue this research or to the people who interest to the fiscal management as follows:

1. The follow up research that exposes the detail of each variable in this research is necessary. Specially to the other factors that did not observed ion this research, i.e. (1) the role of society participation in budgeting process and structure, (2) factor influence the role behavior such as motivation, rule, attitude, culture of organization, leadership style and political factor. (3) Factor that related to the good governance, such as principles of strategic vision, justice, law enforcement and consensus orientation. As well as environment and culture factor that influences the good governance. (4) factor that influences local government performance, i.e. motivation, reward, system, regulation, culture of organization and leadership.

2. Legislative institute must increase their managerial function related to the legalization of budget, specially the supervision to activities or programs implemented by executive. The significant and strong influence of the executive role to the realization of good governance depicts that the managerial function on budgeting had understand and implemented effectively. Therefore, in order to maintain and realize a good governance to the best condition, the local government executive must take a serious efforts in strengthening of human resources, especially in local financial management or budgeting. The knowledge and experiences factor must be enhanced and empowered. Both of these aspects are important elements in the increasing of competency of local government executive through the formal education related to the budgeting management or non formal education through course and training either for leader group or for the organizer level.

\section{References}

[1]. Allen, Richard \& Tommasi, Daniel. 2000. Managing Public Expenditure: A Reference book for transition Countries. OECD.

[2]. Asian Development Bank. 2000. Review of for Managing Public Expenditure, ADB. Manila, Philipine.

[3]. Castaneda, Xandro. 2000. Managing and Monitoring Budget Implementation, Asian Development Bank. Manila, Philipine.

[4]. Goddard, Andrew. 1999. "Culture and Drama: The role of financial control system in the organisational process in three local government organisations". The International Journal of Public Sector Management. Vol 12.

[5]. Hackbart, Merl \& Ramsey, Jim. 1999. Managing Public Resources: Budget Execution. Journal of Public Budgeting, Accoounting \& Financial Management. Boca Raton.

[6]. Joko Widodo. 2001. Good Governance, Telaah dari Dimensi: Akuntabilitas dan Kontrol Biriokrasi, Pada Era Desentralisasi dan Otonomi Daerah. Surabaya: Penerbit Insan Cendekia.

[7]. Mardiasmo. 2004. Otonomi \& Manajemen Keuangan Daerah. Yogyakarta : Penerbit Andi.

[8]. Osborne, David and Gaebler, Ted . 1992. "Reinventing Government: How the Entrepreneurial Spirit Is transforming the Public Sector". Penguins Books, New York.

[9]. Pelizzo, Ricardo, Rick Stapenhurst \& David Olson. 2005. "The Role of Parliaments in the Budget Process". World Bank Institute. Washington.

[10]. Premchand, Arigapudi.2000. Public Financial Management: Getting the Basics Right.Asian Development Bank, Manila, Philipine. 
[11]. Republik Indonesia, Undang-Undang No. 32 Tahun 2004 tentang Pemerintahan Daerah. Jakarta.

[12]. Undang-Undang No 32 tahun 2004 tentang Perimbangan Keuangan antara Pemerintah Pusat dan Daerah. Jakarta.

[13]. Peraturan Pemerintah No. 58 Tahun 2005 tentang Pengelolaan Keuangan Daerah. Jakarta.

[14]. Santiso, Carlos.2005. "Parliaments and Budgeting: Understanding the Politics of the Budget". UK Department for International Development.

[15]. Sedarmayanti.2003. Good Governance (Pemerintahan Yang Baik); Dalam Rangka Otonomi Daerah. Bandung: Mandar Maju.

[16]. Sekaran, Uma.2003. Research Methods For Business, A Skill-Building Approach, 4th Edition, USA:John Willey and Sons.

[17]. Sevilla, et.al. 1997. Research Method, Revised Edition. Manila: Printing Company. Schick,

[18]. Allen. 2002., Can National Legislatures Regain an Effective Voice in Budget Policy”. Journal of Budgeting.

[19]. Stapenhurst, Rick.2004. "The Legislature and the Budget". World Bank.

[20]. Wanath, Taravish \& Kaufman, Dani E.1999. "Toward Transparency in Finance and Governance". The World Bank.

[21]. World Bank. 1997, World Development Report 1997-The State in a Changing World,Washington DC: World Bank.

[22]. 1998. Public Expenditure Management. Washington DC, World Bank.

\section{Regression}

\section{Encloses}

Variables Entered/RemovedP

\begin{tabular}{|l|l|l|l|}
\hline Model & $\begin{array}{c}\text { Variables } \\
\text { Entered }\end{array}$ & $\begin{array}{c}\text { Variables } \\
\text { Removed }\end{array}$ & Method \\
\hline 1 & $\times 2, \times 1^{a}$ & & Enter \\
\hline
\end{tabular}

a. All requested $v$ ariables entered.

b. Dependent Variable: Y1

Model Summary

\begin{tabular}{|l|r|r|r|r|}
\hline Model & $\mathrm{R}$ & $\mathrm{R}$ Square & $\begin{array}{c}\text { Adjusted } \\
\mathrm{R} \text { Square }\end{array}$ & $\begin{array}{c}\text { Std. Error of } \\
\text { the Estimate }\end{array}$ \\
\hline 1 & $.809^{\mathrm{a}}$ & .655 & .612 & 2.640423531 \\
\hline
\end{tabular}

a. Predictors: (Constant), X2, X1

\begin{tabular}{|c|c|c|c|c|c|c|}
\hline \multicolumn{7}{|c|}{ ANOVA } \\
\hline Model & & $\begin{array}{l}\text { Sum of } \\
\text { Squares }\end{array}$ & df & Mean Square & $\mathrm{F}$ & Sig. \\
\hline 1 & Regression & 211.636 & 2 & 105.818 & 15.178 & $.000^{\mathrm{a}}$ \\
\hline & Residual & 111.549 & 16 & 6.972 & & \\
\hline & Total & 323.186 & 18 & & & \\
\hline
\end{tabular}

a. Predictors: (Constant), X2, X1

b. Dependent Variable: $Y 1$

Coefficients ${ }^{a}$

\begin{tabular}{|ll|r|r|r|r|r|}
\hline \multirow{2}{*}{ Model } & \multicolumn{2}{|c|}{$\begin{array}{c}\text { Unstandardized } \\
\text { Coeff icients }\end{array}$} & \multicolumn{2}{|c|}{$\begin{array}{c}\text { Standardized } \\
\text { Coeff icients }\end{array}$} & \multicolumn{1}{|c|}{} \\
\cline { 2 - 4 } & & \multicolumn{1}{|c|}{ B } & Std. Error & \multicolumn{1}{c|}{ Beta } & \multicolumn{1}{c|}{ Sig. } \\
\hline 1 & (Constant) & 14.490 & 18.276 & & .793 & .439 \\
& X1 & 1.478 & .278 & .799 & 5.313 & .000 \\
& X2 & .126 & .445 & .042 & .282 & .781 \\
\hline
\end{tabular}

a. Dependent Variable: $\mathrm{Y} 1$

Coefficients

\begin{tabular}{|ll|r|r|r|r|r|}
\hline \multirow{2}{*}{ Model } & \multicolumn{2}{|c|}{$\begin{array}{c}\text { Unstandardized } \\
\text { Coeff icients }\end{array}$} & \multicolumn{2}{c|}{$\begin{array}{c}\text { Standardized } \\
\text { Coefficients }\end{array}$} & \\
\cline { 3 - 5 } & & \multicolumn{1}{|c|}{ B } & Std. Error & \multicolumn{1}{|c|}{ Beta } & \multicolumn{1}{c|}{ S } & \multicolumn{1}{c|}{ Sig. } \\
\hline 1 & (Constant) & -5.465 & 4.853 & & -1.126 & .277 \\
& X1 & .357 & .074 & .746 & 4.837 & .000 \\
& X2 & .127 & .118 & .165 & 1.072 & .300 \\
\hline
\end{tabular}

a. Dependent Variable: Y2 